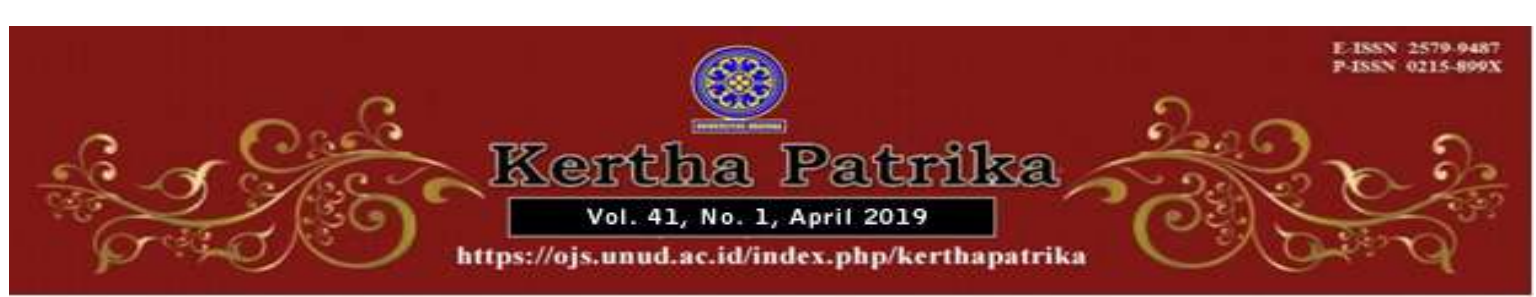

\title{
Keabsahan Kontrak Kemitraan Youtube Kepada Anak Sebagai Mitra Youtube
}

\author{
Albert Jackson Korassa Sonbai ${ }^{1}$
}

1LBH-HPP-PETA Cab.Bali, E-mail: albertjackson38@yahoo.co.id

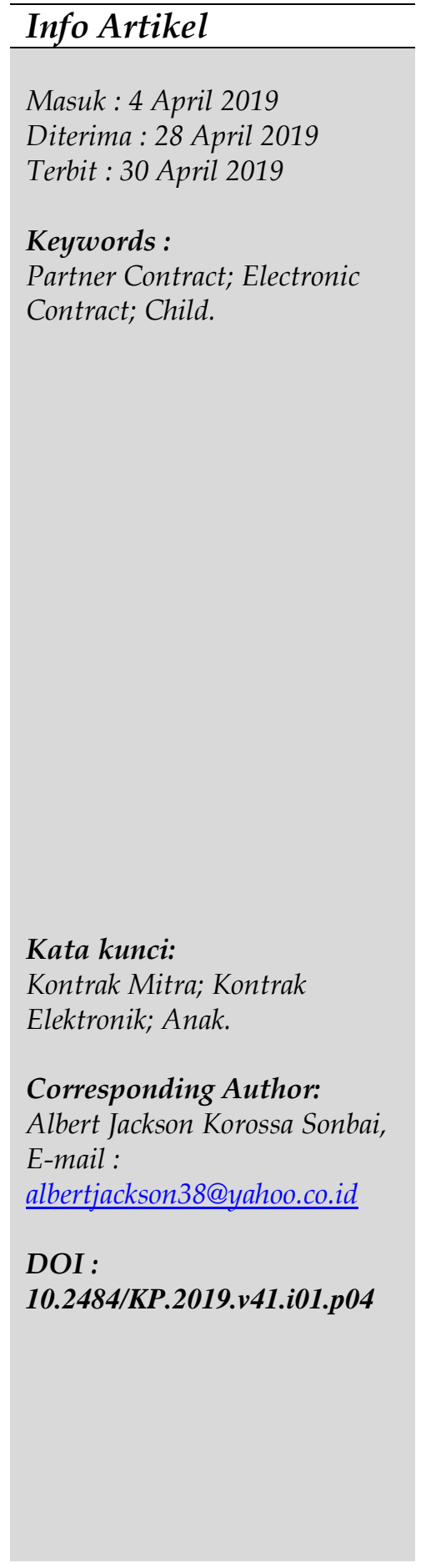

\begin{abstract}
Electronic partnership contracts have made it easier for everyone to partner, including being a youtube partner. Youtube is not only binding on adults who are youtube partners but children are also youtube partners. The validity of youtube partner contracts on children is a problem and a legal consequence of the contract carried out by the child. The purpose of this paper is to examine the validity of partnership contracts carried out by youtube to incompetent children according to Article 47 of the Government Regulation of the Republic of Indonesia Number 82 of 2012 and to know the legal consequences of partnership contracts carried out by children. The research method used is normative legal research with regulatory approach. The study shows that youtube partnership contracts to children as youtube partners with electronic media must be in accordance with Article 47 of the Government Regulation of the Republic of Indonesia Number 82 of 2012 and Article 1320 of the Civil Code where proficiency is one of the requirements for electronic contracts considered valid, if they do not meet the requirements the condition that the partnership contract through electronic media is invalid. The legal consequences of partner contracts through electronic media carried out by children can be canceled through the court to cancel such contract. If there is no objection and cancellation by either party, the electronic partner contract remains valid and binding on the parties.
\end{abstract}


dianggap sah, apabila tidak memenuhi syarat-syarat maka kontrak kemitraan melalui media elektronik adalah tidak sah. Akibat hukum kontrak mitra melalui media elektronik yang dilakukan oleh anak adalah dapat dibatalkan melalui pengadilan untuk membatalkan kontrak tersebut. Apabila tidak ada keberatan dan pembatalan oleh salah satu pihak maka kontrak mitra elektronik tetap sah dan mengikat para pihak.

\section{Pendahuluan}

Perkembangan teknologi dengan cepat membawa perubahan dalam segala aspek kehidupan masyarakat, semakin canggih dan berkembangnya teknologi dapat mengubah pola hidup masyarakat, masyarakat yang dahulu menonton program maupun video hanya melalui televisi, dapat mengakses program televisi dan video melalui website dan handphone, salah satu inovasi teknologi terbaru dalam bidang menonton dan berbagi video adalah youtube. Youtube merupakan Situs yang memberikan fasilitas mengunggah, menonton, dan berbagi video. Mitra youtube yang dikenal sebagai youtuber, dapat membuat video kreasinya sendiri dan mengunggah videonya ke dalam youtube dan mendapatkan pundi-pundi uang dari video yang diunggahnya.

Perkembangan teknologi membawa dampak pada sektor hukum berkaitan dengan hukum kontrakdimana dahulu sistem transaksi perdagangan dan pekerjaan semula berbasis kertas berubah menjadi sistem digital. Namun, pengaturan hukum kontrak elektronik belum dapat sepenuhnya dijangkau oleh pengaturan hukum kontrak konvensional, seperti youtube melakukan kontrak elektronik kemitraan youtube. Hubungan hukum yang mengikat antara youtube dan mitranya menggunakan kontrak elektronik kemitraan. Perjanjian kemitraan dapat diartikan sebagai suatu kesepakatan dua orang atau lebih, berisikan hak dan kewajiban para pihak dengan dasar saling percaya, saling memerlukan dan saling menguntungkan para pihak.

Perjanjian kemitraan menandai perkembangan perikatan bisnis yang di dalamnya terdapat suatu kepentingan antara kedua belah pihak yang dapat dilaksanakan segera dengan cepat. ${ }^{1}$ Youtube dalam kontrak elektronik kemitraan menggunakan perjanjian baku untuk mengikat mitranya sehingga pihak yang yang mengikatkan diri sebagai mitra youtube harus mengikuti semua peraturan youtube yang tertuang dalam kontrak kemitraan elektronik youtube.

Youtube tidak hanya mengikat orang dewasa atau subjek yang cakap hukum untuk menjadi mitra youtube namun terdapat account Youtube yang dimiliki oleh anak sebagai mitra youtube seperti channel youtube Dafa Tewaaz berumur 16 tahun dengan 91.000 Subscribers dan Yosafat Kartono berumur 15 tahun dengan 24.823 subscribers dan mendapatkan penghasilan dari youtube. Kontrak elektronik kemitraan yang dilakukan oleh anak sebagai subjek hukum yang tidak cakap belum dapat dikatakan mengikat

1 Pribadi, D. S. (2018). Penerapan Asas Proporsionalitas/Berimbang Dalam Perjanjian Kemitraan. Yuriska: Jurnal Ilmiah Hukum,10(1).h. 29. 
dan sah, sebagaimana tertuang dalam Pasal 47 Peraturan Pemerintah Republik Indonesia No.82 Tahun 2012 Tentang Penyelenggaraan Sistem dan Transaksi Elektronik (selanjutnya disebut PP PSTE) salah satu syarat kontrak elektronik dianggap sah ketika dilakukan oleh subjek hukum yang cakap, apabila dilakukan oleh subjek hukum yang cakap, kontrak elektronik akan mengikat para pihak sebagaimana tertuang dalam pasal 18 Ayat (1) Undang-undangNo.19 Tahun 2016 Tentang Perubahan Atas Undang-Undang Nomor 11 Tahun 2008 Tentang Informasi dan Transaksi Elektronik (selanjutnya disebut UU ITE).

Dalam studi ini, berdasarkan latar belakang di atas, dapat diajukan permasalahannya sebagai berikut: bagaimanakah keabsahan kontrak elektronik kemitraan yang dilakukan oleh youtube dengan anak menurut Pasal 47 PP PSTE?dan bagaimanakah akibat hukum dari kontrak elektronik kemitraan youtube terhadap anak sebagai mitranya?

Tujuan dari studi ini adalah menjelaskan dan memberikan jawaban terhadap keabsahan kontrak elektronik kemitraan yang dilakukan oleh youtube kepada anak sebagai subjek hukum yang tidak cakap menurut Pasal 47 PP PSTE serta mengetahui akibat hukum dari kontrak elektronik kemitraan yang dilakukan oleh anak.

Studi yang memiliki kesamaan dengan tulisan ini namun berbeda fokus permasalahan diantaranya Debby Tri Sebbiana Tarigan. I Wayan Wiryawan \& I Nyoman Mudana tahun 2017 melakukan studi yang berjudul Analisis Perjanjian Kerjasama Kemitraan PT.GO-JEK Dengan Driver berdasarkan Undang-Undang No.13 Tahun 2003 Tentang Ketenagakerjaan. Secara umum penelitian tersebut memiliki objek yang sama dengan studi ini yakni terkait dengan Perjanjian Kemitraan². Lebih lanjut, Ridwan Khairandy pada tahun 2001 melakukan studi yang berjudul Pembaharuan Hukum Kontrak sebagai Antisipasi Transaksi Electronic Commerce mengkaji mengenai bentuk-bentuk kontrak e-commerce dan bentuk-bentuk kontrak konvensional, pengaturan-pengaturan kontrak e-commerce ${ }^{3}$. Studi-studi yang telah dikemukakan sebelumnya meskipun juga berkaitan dengan kontrak kemitraan dan kontrak e-commerce, namun analisisnya tidak berfokus pada keabsahan kontrak elektronikkemitraan youtube dengan anak sebagai subjek yang tidak cakap.

\section{MetodePenelitian}

Penelitian tentang keabsahan kontrak kemitraan youtube kepada anak sebagai mitra youtube merupakan penelitian hukum normatif. Dengan pendekatan undang-undang (statute approach), dengan menelaah undang-undang Nomor 19 Tahun 2016 Tentang Perubahan atas Undang-undang Nomor 11 Tahun 2008 Tentang Informasi dan Transaksi Elektronik dan Peraturan Pemerintah RI Nomor 82 Tahun 2012 Tentang Penyelenggaraan Sistem dan Transaksi Elektronik. Bahan hukum primer dan bahan

2 Tarigan,D.T.S, Wiryawan, I. W., \& Mudana, I. N. (2017). Analisis Perjanjian Kerjasama Kemitraan PT.Go-jek Dengan Driver Berdasarkan Undang-Undang No. 13 Tahun 2003 Tentang Ketenagakerjaan. Kertha Semaya,5(2), 1-14. h. 7.

3 Khairandy, R. (2001). Pembaharuan Hukum Kontrak Sebagai Antisipasi Transaksi Electronic Commerce. IusQuiaIustum Law Journal, 8(16). doi: http://dx.doi.org/10.20885/iustum.vol8.iss16.art4, h .48 
hukum sekunder digunakan dalam penulisan ini. Bahan hukum sekunder yang dipakai ialah berupa publikasi hukum atau komentar atau keputusan pengadilan.

\section{Hasil Dan Pembahasan}

\subsection{Keabsahan Kontrak Kemitraan yang Dilakukan Oleh Youtubedengan Anak Menurut Pasal 47 PP PSTE.}

Perjanjian kemitraan dapat diartikan sebagai suatu persetujuan yang dibuat dua subjek hukum atau lebih dengan hak dan kewajiban tiap-tiap pihak berdasarkan prinsip saling percaya,memerlukan dan menuntungkan para pihak. Perjanjian kemitraan tunduk pada ketentuan Pasal 1338 jo Pasal 1320 KUH Perdata. ${ }^{4}$ Pasal 1618-1641 BWmengatur khusus ketentuan kemitraan pada ketentuan persekutuan perdata. Pasal 1618 BW mendefinisikan persekutuan adalah persetujuan dua orang atau lebih sepakat mengikatkan diri dalam persekutuan untuk membagi keuntungan. Selanjutnya pasal 1619 BW mendifinisikan bahwa antar pihak persekutuan bersama-sama memasukkan modal berupa barang, uang, kerajinan atau tenaganya.

Perbuatan hukum melaksanakan perjanjian kemitraan elektronik merupakan bentuk dari transaksi elektronik, sebagaimana Pasal 1 angka 2 UU ITE memberikan definisi transaksi elektronik merupakan perbuatan hukum yang dilakukan dengan menggunakan komputer, jaringan komputer, dan/atau media elektronik lainnya. Transaksi elektronik terjadi pada saat penawaran transaksi yang dikirim oleh pengirim telah diterima dan disetujui oleh penerima dengan pernyataan secara elektronik.

Youtube sebagai perusahaan penyedia aplikasi dengan penyedia tempat untuk mitranya mengunggah videonya kedalam aplikasinya mengikat mitra-mitranya dengan kontrak elektronik kemitraan, kontrak melalui media elektronik dikenal dengan nama kontrak elektronik, dimana pasal 1 angka 17 UU ITE mendefinisikan kontrak elektronik merupakan perjanjian para pihak dibuat melalui sistem elektronik. Dan untuk dikatakan sah kontrak elektronik, harus dilakukan oleh subjek hukum yang cakap sebagaimana tertuang dalam Pasal 47 ayat (2) huruf (c)PP PSTE.

Kontrak elektronik mempunyai karakter yang berbeda dengan kontrak pada umumnya, yaitu :

a. Kehadiran fisik sudah tidak diperlukan,

b. Kontrak terjadi dalam jaringan internet,

c. Kontrak dapat dilakukan dari jarak jauh, seperti antar negara. ${ }^{5}$

Kontrak elektronik kemitraan youtube kepada anak sebagai subjek yang tidak cakap dapat mempengaruhi keabsahan kontrak itu sendiri, adapun hal-hal dan faktor-faktor yang dapat mempengaruhi keabsahan kontrak,yaitu:

4 Nasution,D.M.A. (2018). Tinjuan Hukum Terhadap Layanan Transaksi dan Transportasi Berbasis Aplikasi Online. RESAM: Jurnal Hukum, 4(1).doi: https://doi.org/10.32661/resam.v4i1.10, h. 26.

5 Ikhsan, M.A. (2018). Keabsahan Kontrak Kerja Freelance Dengan Media Digital Di Amazone Pontianak Dalam Pandangan Hukum Islam Kontemporer. Al-Maslahah, 14(1). doi: https://doi.org/10.24260/al-maslahah.v14i1.1010,h. 148. 
1. Faktor-faktor yang merusak. Keabsahan sebuah kontrak bisa jadi cacat dalam salah satu situasi sebagai berikut :

(a) Kalamana elemen kesepakatan cacat atau rusak karena :

(i) Kesalahan, dimana salah satu pihak atau kedua belah pihak mengikat kontrak dengan pemahanan yang salah; atau,

(ii) Misrepresentasi (salah/keliru penggambarannya), salah satu pihak didorong untuk menyepakati suatu hal karena representasi yang salah atau keliru dari pihak lain; atau,

(iii) Tekanan atau pengaruh dari pihak lain, maksudnya tekanan langsung atau tekanan halus yang diterima oleh pihak yang mengikat kontrak.

(b) Bilamana satu pihak atau lebih yang berkontrak tidak cakap dan tidak memiliki kapasitas penuh untuk mengikat kontrak.

(c) Bilamana kontrak tersebut ilegal.

(d) Bilamana sebuah kontrak,sebagian atau seluruhnya, batal menurut hukum perdata karena bertentangan dengan kebijakan publik.

2. Kontrak yang rusak. Bilamana dalam sebuah kontrak terdapat faktor yang merusak, konsekuensi hukumnya akan beragam menurut situasi, sebagai berikut :

(a) Batal atau tidak ada atau kosong, artinya kontrak yang batal mutlak, tidak bermakna sama sekali.

(b) Dapat dibatalkan, artinya kontrak yang menimbulkan konsekuensikonsekuensi hukum, tapi mungkin dikesampingkan atau diabaikan.

(c) Ilegal, artinya kontrak yang tidak dapat digugat kecuali dalam situasi-situasi khusus.

(d) Tidak dapat dilaksanakan, artinya kontrak yang baik namun penggugat tidak dapat mengajukan gugatan kehadapan hukum karena tidak adanya bukti tertulis ketika dibutuhkan, atau karena adanya cacat atau kekurangan kapasistas tergugat untuk mengadakan kontrak. ${ }^{6}$

Kontrak kemitraan youtube dengan anak/subjek yang tidak cakap merupakan kontrak elektronik dikarenakan menggunakan media elektronik untuk mengikat mitranya. Dengan demikian syarat-syarat sahnya kontrak elektronik di atur dalam Pasal 47 ayat (2) PP PSTE yang mengatur bahwa Kontrak Elektronik harus dilakukan oleh subjek yang cakap, syarat-syarat sahnya kontrak elektronik dalam Pasal 47 ayat (2) PP PSTE berkesesuaian dengan Pasal 1320 BW yang mengatur bahwa syarat-syarat sahnya suatu perjanjian, yaitu :

1. Sepakat mereka yang mengikatkan dirinya;

2. Kecakapan untuk membuat suatu perikatan;

3. Suatu hal tertentu;

4. Suatu sebab yang halal.

Penjelasan pasal 1320 KUH Perdata dapat dibedakan menjadi :

1. Syarat subyektif

6 Major, T.W. (2018). Hukum Kontrak. Bandung:Nuansa Cendekia, h. 90. 
a. Sepakat, dimana dalam perjanjian harus ada kata sepakat tanpa adanya suatu tekanan maupun paksaan dari pihak manapun

b. Kecakapan, dimana subjek hukum yang terikat dalam perjanjian harus cakap dan tidak dalam pengampuan atau sakit jiwanya

2. Syarat objektif

a. Suatu hal tertentu, dimana hal yang diperjanjikan harus jelas sehingga hak dan kewajiban dapat terlaksana antar para pihak dan keempat

b. Suatu sebab yang halal, dimana perjanjian tidak boleh bertentangan dengan Undang-undang, kesusilaan dan ketertiban umum.

Kontrak elektronik mempunyai syarat-syarat sahnya kontrak elektronik dalam pasal 47 ayat (2) PP PSTE dan tidak terlepas dari syarat-syarat Pasal 1320 BWdimana syarat sahnya perjanjian dalam angka (2) yang menyatakan bahwa syarat sahnya perjanjian harus dilakukan oleh subjek yang cakap atau dewasa.Kecakapan dalam melakukan perbuatan hukum dipengaruhi oleh umur dan status telah ataupun pernah kawin. Namun, dalam penjelasan pasal 47 ayat 2 huruf (b) PP PSTE mengenai kecakapakan dikatakan cukup jelas tanpa menyebutkan umur berapakah dikatakan cakap dalam pasal tersebut, peraturan perundang-undangan di Indonesia mengenai batas usia seseorang yang dikategorikan sebagai dewasa atau subjek yang cakap hukum masih belum ada kesepakatan pada umur berapakah subjek hukum dikatakan cakap, diantaranya :

\begin{tabular}{|c|c|c|}
\hline No. & Peraturan Perundang-undangan & Penjelasan mengenai batas umur anak \\
\hline 1. & $\begin{array}{l}\text { Kitab Undang-Undang Hukum } \\
\text { Perdata }\end{array}$ & $\begin{array}{l}\text { Anak adalah belum mencapai umur } 21 \\
\text { tahun dan belum pernah kawin. (Pasal } \\
330 \text { BW) }\end{array}$ \\
\hline 2. & $\begin{array}{lll}\text { Kitab } & \text { Undang-Undang } & \text { Hukum } \\
\text { Pidana } & & \end{array}$ & $\begin{array}{l}\text { Anak adalah belum berumur } 21 \text { tahun } \\
\text { dan belum pernah kawin. (Pasal } 295 \\
\text { KUHP) }\end{array}$ \\
\hline 3. & $\begin{array}{l}\text { Undang-Undang No.1 Tahun } 1974 \\
\text { Tentang Perkawinan }\end{array}$ & $\begin{array}{l}\text { a. Izin orang tua apabila belum } \\
\text { mencapai } 21 \text { tahun (Pasal } 6 \text { ayat } \\
(2)) ; \\
\text { b. Pria berumur } 19 \text { tahun dan wanita } \\
16 \text { tahun (Pasal } 7 \text { ayat (2)); }\end{array}$ \\
\hline & $\begin{array}{l}\text { Undang-Undang No. } 39 \text { Tahun } 1999 \\
\text { Tentang Hak Asasi Manusia. }\end{array}$ & $\begin{array}{l}\text { Anak adalah umur } 18 \text { tahun termasuk } \\
\text { yang berada didalam kandungan dan } \\
\text { belum menikah }\end{array}$ \\
\hline
\end{tabular}

Berdasarkan pada uraian tabel diatas, belum adanya kesepakatan batas umur seseorang di kategorikan sebagai subjek yang cakap hukum atau dewasa. Persoalan umur dalam melakukan perbuatan hukum tidaklah dapat dikesampingkan karena apabila dilihat dalamsudut pandang keperdataan sangat penting mengingat hal tersebut berkaitan dengan kecakapan seseorang dalam bertindak guna mendapatkan 
hak-hak tertentu. ${ }^{7}$ Dalam perkembangannya Mahkamah Agung melalui Putusan No. 447/Sip/1976 tanggal 13 Oktober 1976 menyatakan bahwa dengan berlakunya UU No. 1 Tahun 1974, maka batas seseorang berada dibawah kekuasaan perwalian adalah 18 tahun, bukan 21 tahun. Selain unsur umur, Pasal 1330 BW mengatur subjek hukum yang tidak cakap adalah mereka yang ditaruh di bawah pengampuan.

Jika menelaah kontrak kemitraan youtube dan anak maka kontrak kemitraan kemitraan tersebut melanggar beberapa peraturan yang berlaku di Indonesia antara lain adalah :

1. PP PSTE.

Ketentuan Pasal 47 ayat (2) yang secara tegas menyatakan bahwa Kontrak elektronik dianggap sah apabila dilakukan oleh subjek yang cakap.

2. BW.

Ketentuan Pasal 1320 BW dimana kecakapan merupakan salah satu syarat untuk perjanjian dapat dikatakan sah .

Berdasarkan uraian di atas telah ditemukan adanya indikasi pelanggaran terhadap beberapa peraturan di Indonesia. Jika menelaah kontrak kemitraan youtube terhadap anak sebagai mitranya, youtube menggunakan asas kebebasan kontrak (Pasal 1338 BW) dengan mengabaikan kecapakan seseorang sebagai syarat dalam kontrak mitranya, hal ini termuat dalam kontrak kemitraan youtube pada persyaratan program mitra youtube, youtube tidak memberikan batas umur untuk menjadi mitra youtube dalam persyaratan program mitra youtube.

Kontrak Mitra youtube yang mengabaikan kecakapan mitranya melanggar Pasal 47 ayat (2) huruf (b) PP PSTE yang menyatakan bahwa kontrak elektronik harus dilakukan oleh subjek hukum yang cakapdan Pasal 1320 ayat (2) BW yang mengatur Kecakapan untuk membuat suatu perikatan, berdasarkan hal-hal tersebut kontrak mitra youtube terhadap anak menurut Pasal 47 ayat 2 huruf (b) PP PSTE adalah tidak sah, karena tidak memenuhi syarat kecakapan bertindak oleh anak.

\subsection{Akibat Hukum dari Kontrak Kemitraan Youtube Terhadap Anak yang Tidak Cakap sebagai Mitranya.}

Kebebasan untuk menyatakan kehendak berlaku ketika para pihak menyatakan kata sepakat dan saling mengikatkan diri, meskipun ada pembatasan-pembatasan atas kebebasan menyatakan kehendak atau dikenal dengan asas kebebasan berkontrak yang tertuang dalam pasal 1338 BW. Dengan asas kebebasan berkontrak setiap orang diakui memiliki kebebasan untuk membuat kontrak dengan siapapun juga, menentukan isi kontrak, menentukan bentuk kontrak, memilih hukum yang berlaku bagi kontrak yang bersangkutan ${ }^{9}$. Namun batasan terhadap kebebasan berkontrak belum optimal dan menimbulkan keadaan yang tidak terbatas. Kebebasan berkontrak menimbulkan konsenkuensi seolah-olah suatu pernyataan kepada individu yang

7 Ginting, T. E., \& Westra, I. K. (2018).Perkawinan Anak di Bawah Umur Dilihat Dari Perspektif Hukum Pidana. Jurnal Kertha Wicara Fakultas Hukum Universitas Udayana, 7(3), 115.h.12.

8 Khairandy, R.Loc.cit. h.48.

9 Khairandy, R. (2011). Landasan Filosofis Kekuatan Mengikatnya Kontrak. Jurnal Hukum IUS QUIA IUSTUM, 18. h.37. 
membuat perjanjian diperbolehkan membuat perjanjian sesuai kehendaknya dan perjanjian itu akan mengikat mereka yang membuatnya dan menjadi undang-undang. Kebebasan individu dalam berkontrak didasari dari kebebasan berkontrak. Dengan demikian setiap individu mempunyai kebebasan untuk berkontrak demi kepentingannya.

Larangan kepada seseorang ketika membuat perjanjian dalam bentuk tertentu sesuai yang dikehendaki tidak diatur dalam peraturan Undang-undang maupun BW. Akan tetapi ada beberapa pembatasan oleh BW terhadap asas kebebasan berkontrak, dalam Pasal 1338 BW terdapat suatu batasan dimana perjanjian harus dibuat "secara sah" sehingga dapat menjadi undang-undang bagi mereka yang membuatnya. Sehingga dapat disimpulkan sebagai pernyataan kepada setiap orang, bahwa setiap orang memiliki kebebasan menyatakan kehendaknya dalam membuat perjanjian, asalkan kebebasan dalam membuat perjanjian tidak bertentangan dengan Pasal 1320 BW maupun perundang-undangan lainnya, kesusilaan dan ketertiban umum.

Kontrak kemitraan youtube dengan anak/subjek yang tidak cakap merupakan kontrak elektronik dikarenakan menggunakan media elektronik untuk mengikat mitranya. Dengan demikian syarat-syarat sahnya kontrak elektronik di atur dalam Pasal 47 ayat (2) PP PSTE yang mengatur bahwa Kontrak Elektronik harus dilakukan oleh subjek yang cakap , syarat-syarat sahnya kontrak elektronik dalam Pasal 47 ayat (2) PP PSTE berkesesuaian dengan Pasal 1320 BW yang mengatur bahwa syarat-syarat sahnya suatu perjanjian, yaitu :

1. Sepakat mereka yang mengikatkan dirinya;

2. Kecakapan untuk membuat suatu perikatan;

3. Suatu hal tertentu;

4. Suatu sebab yang halal.

Penjelasan pasal 1320 KUH Perdata dapat dibedakan menjadi :

1. Syarat subyektif

c. Sepakat, dimana dalam perjanjian harus ada kata sepakat tanpa adanya suatu tekanan maupun paksaan dari pihak manapun

d. Kecakapan, dimana subjek hukum yang terikat dalam perjanjian harus cakap dan tidak dalam pengampuan atau sakit jiwanya

2. Syarat objektif

c. Suatu hal tertentu, dimana hal yang diperjanjikan harus jelas sehingga hak dan kewajiban dapat terlaksana antar para pihak dan keempat

d. Suatu sebab yang halal, dimana perjanjian tidak boleh bertentangan dengan Undang-undang, kesusilaan dan ketertiban umum.

Adapun akibat hukum apabila syarat sahnya kontrak tidak terpenuhi, yaitu :

1. Kontrak batal demi hukum, kontrak tidak memenuhi syarat obyektif. Syarat objektif dari suatu kontrak adalah suatu hal tertentu dan suatu sebab yang halal sebagaimana yang tecantum di dalam Pasal 1320 BW. Jika kekurangan itu berkaitan dengan syarat objektif, yakni tiadanya syarat objek tertentu bertentangan dengan 
kausa yang halal, maka kontrak tersebut batal demi hukum. Artinya sejak awal sudah tidak dan dianggap tidak pernah ada. ${ }^{10}$

2. Kontrak dapat dibatalkan, kontrak tidak memenuhi syarat subyektif. Syarat subyektif ialah tidak ada kata sepakat antar para pihak dan tidak cakapnya subjek hukum yang melakukan perjanjian.

Sebuah kontrak elektronik yang dibuat oleh seorang anak atau belum dewasa dapat berakibat hukum :

1. Kontrak dapat dibatalkan atas permintaan salah satu pihak melalui gugatan perdata dan putusan pengadilan

Kontrak yang dilakukan oleh anak dapat dibatalkan,apabila kontrak telah dilaksanakan ada pihak yang keberatan dan mengajukan pembatalan kontrak ke pengadilan, melalui pengadilan kontrak dapat dibatalkan dengan putusan pengadilan. Putusan pengadilan merupakan hal yang diperlukan untuk pembatalan kontrak. Pihak yang keberatan harus mengajukan gugatan pembatalan kontrak kepada pengadilan agar dapat membatalkan kontrak tersebut. Apabila pengadilan mengabulkan gugatan tersebut, maka kontrak yang mengikat para pihak yang dibatalkan tersebut menjadi batal dan dianggap kembali seperti semula. Kontrak yang dibatalkan oleh pengadilan dengan putusan pengadilan mengakibatkan kontrak menjadi batal dan tidak mengikat para pihak. Jika terjadi pembatalan oleh Putusan Pengadilan maka kontrak berakhir, kewajiban yang telah dilaksanakan dapat dikembalikan seperti sebelum melakukan perjanjian.

2. Kontrak dapat dibatalkan kedua belah pihak melalui kesepakatan para pihak

Kontrak dapat dibatalkan kedua belah pihak melalui kesepakatan para pihak pada prinsipnya kontrak dapat dibatalkan dengan persetujuan kedua belah pihak tanpa melalui proses gugatan dan putusan pengadilan sehingga ketika para pihak sepakat untuk membatalkan kontrak, maka saat itu juga kontrak telah dibatalkan dan tidak mengikat para pihak.

3. Kontrak tetap mengikat si anak

Kontrak tetap mengikat si anak sepanjang antar para pihak tidak ada yang meminta pembatalan kontrak kepada pengadilan, kontrak tetap sah dan mengikat. Walaupun kontrak mitra elektronik yang dilakukan oleh anak tetap dikatakan sah, para pihak tetap menjalankan kontrak dengan etikat baik, sebagaimana tertuang dalam Pasal 1338. Tanpa adanya keberatan dan meminta pembatalan kontrak ke pengadilan oleh salah satu pihak dalam kontrak mitra melalui media elektronik, kontrak mitra yang dilakukan oleh anak adalah sah menurut hukum, adil dan memberikan perlindungan kepada para pihak dalam kontrak mitra tersebut.

10 Panggabean, R.M. (2010). Keabsahan Perjanjian Dengan Klausul Baku. Jurnal Hukum IUS QUIA IUSTUM , 17(4).doi: https:// doi.org/10.20885/iustum.vol17.iss4.art8, h. 663. 
Kontrak elektronik kemitraan yang dilakukan oleh youtube terhadap anak atau sebagai subjek hukum yang tidak cakap dapat dibatalkan baik melalui pengadilan maupun dapat tetap mengikat anak, hal ini sesuai dengan Subjective theory of contract atau teori kontrak subjektif yang dikemukakan oleh Wayne Barnes. Dimana, subjective theory of contract atau teori kontrak subjektif difokuskan pada bertemunya kehendak atau keinginan para pihak. Para pihak harus benar-benar untuk menyetujui kesepakatan yang telah dibuat antara keduanya. Teori kontrak ini hanya mengikat orang-orang yang telah ditentukan secara jelas dan subjeknya bertujuan mengikatkan dirinya dengan pihak lainnya. Dengan demikian, kebebasan para pihak di atas segalagalanya. ${ }^{11}$

Teori kontrak subjektif yang dikemukakan oleh Wayne Barnes berkesusaian dengan kontrak kemitraan youtube melalui media elektronik yang menerapakan asas kebebasan berkontrak yang tetap mengikat anak dan youtube walaupun anak adalah subjek hukum yang tidak cakap dan melanggar ketentuan Pasal 47 PP PSTE dan Pasal 1320 BW mengenai kecakapan dalam syarat-syarat sahnya perjanjian. Sepanjang tidak ada keberatan dan pembatalan dari putusan pengadilan maka kontrak kemitraan youtube dan anak melalui media elektronik adalah sah dan mengikat para pihak.

\section{Kesimpulan}

Kontrak kemitraan youtube kepada anak sebagai mitra youtube dengan media elektronik harus sesuai dengan pasal 47PP PSTE dan pasal 1320 BWdimana kecakapan adalah salah satu syarat untuk kontrak elektronik dianggap sah. Apabila tidak memenuhi syarat-syarat maka kontrak kemitraan melalui media elektronik adalah tidak sah. Akibat hukum kontrak mitra melalui media elektronik yang dilakukan oleh anak adalah dapat dibatalkan melalui pengadilan untuk membatalkan kontrak mitra elektronik. Apabila tidak ada keberatan dan pembatalan oleh salah satu pihak maka kontrak mitra elektronik tetap sah dan mengikat para pihak.

\section{Ucapan terima kasih (Acknowledgments)}

Ucapan terima kasih diberikan kepada seluruh pihak yang telah membantu dalam penulisan dan penyempurnaan artikel ini. Khususnya Lembaga Bantuan Hukum Himpunan Penerus Pejuang Pembela Tanah Air (LBH-HPP-PETA) Cabang Bali yang telah membantu dan memberikan semangat kepada penulis. Selain itu segenap rekanrekan Civitas Akademika Universitas Udayana yang telah memberikan dukungan pemikiran serta dukungan-dukungan lainnya yang tidak dapat penulis uraikan.

\section{DAFTAR PUSTAKA}

\section{Buku}

Major, T.W. (2018). Hukum Kontrak. Bandung:Nuansa Cendekia.

Salim, H. S. \& Nurbani, E. S. (2015). Penerapan Teori Hukum Pada Penelitian Disertasi dan Tesis. Jakarta:PT.RajaGrafindo Persada.

\footnotetext{
11Salim,H.S.\& Nurbani,E.S. (2015). Penerapan Teori Hukum Pada Penelitian Disertasi Dan Tesis. Jakarta:PT.RajaGrafindo Persada, h.245.
} 


\section{Jurnal}

Ginting, T. E., \& Westra, I. K. (2018). Perkawinan Anak di Bawah Umur Dilihat Dari Perspektif Hukum Pidana. Jurnal Kertha Wicara Fakultas Hukum Universitas Udayana, 7(3): 1-15.

Ikhsan, M.A. (2018). Keabsahan Kontrak Kerja Freelance Dengan Media Digital Di Amazone Pontianak Dalam Pandangan Hukum Islam Kontemporer. Al-Maslahah, 14(1). doi: https://doi.org/10.24260/al-maslahah.v14i1.1010.

Khairandy, R. (2001). Pembaharuan Hukum Kontrak Sebagai Antisipasi Transaksi Electronic Commerce. Ius Quia Iustum Law Journal, 8(16). doi:http://dx.doi.org/10.20885/iustum.vol8.iss16.art4

Khairandy, R. (2011). Landasan Filosofis Kekuatan Mengikatnya Kontrak. Jurnal Hukum IUS QUIA IUSTUM, 18.

Nasution, D. M. A. (2018). Tinjuan Hukum Terhadap Layanan Transaksi Dan Transportasi Berbasis Aplikasi Online. RESAM : Jurnal Hukum, 4(1).doi: https://doi.org/10.32661/resam.v4i1.10

Panggabean.R.M. (2010). Keabsahan Perjanjian Dengan Klausul Baku. Jurnal Hukum IUS QUIA IUSTUM, 17(4). doi: https://doi.org/10.20885/iustum.vol17.iss4.art8

Pribadi, D. S. (2018). Penerapan Asas Proporsionalitas/Berimbang Dalam Perjanjian Kemitraan. Yuriska: Jurnal Ilmiah Hukum,10(1).

Tarigan, D. T. S., Wiryawan, I. W., \& Mudana, I. N. (2017). Analisis Perjanjian Kerjasama Kemitraan PT.GO-JEK Dengan Driver Berdasarkan UndangUndang No.13 Tahun 2003 Tentang Ketenagakerjaan. Kertha Semaya,15(2), $1-14$.

\section{Peraturan Perundang-undangan}

Kitab Undang-Undang Hukum Perdata

Kitab Undang-Undang Hukum Pidana

Undang-Undang Nomor 1 Tahun 1974 Tentang Perkawinan, Lembaran Negara Republik Indonesia Tahun 1974 Nomor 1. 
Undang-Undang Nomor 39 Tahun 1999 Tentang Hak Asasi Manusia, Lembaran Negara Republik Indonesia Tahun 1999 Nomor 165.

Undang-Undang Nomor 19 Tahun 2016 tentang perubahan atas UndangUndang Nomor 11 Tahun 2008 tentang Informasi dan Transaksi Elektronik, Lembaran Negara Republik Indonesia Tahun 2008 Nomor 58.

Peraturan Pemerintah Republik Indonesia Nomor 82 Tahun 2012 tentang Penyelenggaraan Sistem dan Transaksi Elektronik, Lembaran Negara Republik Indonesia Tahun 2012 Nomor 189. 